\title{
Explaining Kazakhstan's Accession to and Compliance with WTO, from a Neorealism and a Neoliberalism Approach
}

\author{
Jiayuan Chang ${ }^{1, a, ~}{ }^{*} \uparrow$, Weijie Shen ${ }^{2, b, \dagger}$, Jiaxuan $\mathrm{Yu}^{3, \mathrm{c}, \uparrow}$ \\ ${ }^{1}$ School of International Development, University of East Anglia, Norwich, Norfolk, United Kingdom NR4, 7TJ \\ ${ }^{2}$ Shanghai Pinghe School, Shanghai, China 201206 \\ ${ }^{3}$ School Loma Linda Academy, Loma Linda, California, United States CA 92354-2104 \\ *Corresponding author.Email: ${ }^{*}$ neu19nza@uea.ac.uk, ${ }^{b}$ oskarswj@163.com, 'Jamesyu0330@icloud.com \\ These authors contributed equally.
}

\begin{abstract}
The main research topic is to explore why Kazakhstan was accepted to the WTO and comply with its rules. The negotiation and evaluation of the process of Kazakhstan joining the WTO lasted 20 years, including hundreds of terms and conditions. This paper will use both neoliberalism and neorealism approaches in explaining the positive and negative aspects of those terms. With the approaches mentioned, the essay was written based on the case study method. Through the case study of Kazakhstan's accession to WTO and its trade dispute in WTO, the essay explores the motivation behind Kazakhstan's compliance with the WTO. This could later be found in the paper stating that the reason behind Kazakhstan's eagerness to join the WTO even after a prolonged negotiation process was so Kazakhstan could gain economic benefit from facilitated trade and reduce its dependence on Russia to step towards becoming an economic center of Central Asia. In conclusion, the essay deepens our understanding of Kazakhstan's accession to the WTO, the foreign strategy of Kazakhstan, and the function of the WTO in international society. Which could help identify ways of improvement for the WTO and new opportunities in Central Asia development. Some limits of the paper would mostly relate to the lack of evidence and research subjects which points the future studies towards two directions, one being gathering more evidence and gathering more subjects, the second one being to look in-depth into the problems and prospects after the accession of Kazakhstan to the WTO.
\end{abstract}

Keywords: Kazakhstan, WTO, Neorealism, Neoliberalism, Eurasia

\section{INTRODUCTION}

In 2015, Kazakhstan formally became a member of WTO and complied with the terms for entering WTO. Kazakhstan started to apply for its accession in 1995. It took Kazakhstan almost 20 years to finally join in WTO. However, according to WTO, in 2017, Ukraine complained that Kazakhstan's anti-dumping duty was much higher than the standard one in WTO [1]. Consultations have been going on, yet no agreement has been reached yet. Why would Kazakhstan defect the law in WTO only 2 years after its accession? Why would it access WTO in the first place? In the following essay, we will research why Kazakhstan accessed WTO and try to explain its compliance or defection from the perspective of neorealism and neoliberalism.
To give a more specific background, let us first look at Kazakhstan. The Republic of Kazakhstan is a country in Central Asia. It is bounded on the northwest and north by Russia, east by China, and south by Kyrgyzstan, Uzbekistan, the Aral Sea, and Turkmenistan. Kazakhstan is the largest country in Central Asia. The capital is NurSultan (formerly Astana), in the north-central part of the country. Kazakhstan is formerly a constituent republic of the USSR. It declared independence on 12.16.1991. In 2014, Kazakhstan joined the Eurasian Economic Union (EEU). According to Aitolkyn Kourmanova, Kazakhstan seems to be determined to embrace broader integration in global trade [2]. It joined in the Silk Road Economic Belt initiated by China. During the VIII Astana Economic Forum, Kazakhstan's President Nursultan Nazarbayev suggested establishing a common Eurasian economic 
space and called for greater cooperation between the EEU, China, and the European Union.

Back to the research question, we will use the case study of Kazakhstan's accession to WTO and the 2017 trade dispute to study its compliance and defection with WTO. Not to mention the accession that lasted for 20 years, the 2017 trade dispute is also a good case because it exposes the conflict between EEU and WTO (antidumping duty in Kazakhstan is set by EEU). The role of Kazakhstan between these two big IO is especially interesting and meaningful to the research question.

Besides, our research question is important and meaningful. This topic matters because it deepens our understanding of Kazakhstan's accession to WTO, the foreign strategy of Kazakhstan, and the function of WTO in international society. The case may even give strong implications for the role of other post-Soviet countries in WTO and their foreign strategy. Moreover, It can help identify new ways to improve the WTO system to reduce the conflict between WTO and regional organizations like EAEU. Also, the case of Kazakhstan shows new opportunities in Central Asia's development.

The essay is divided into several sections. After the introduction, the essay will examine the literature review and arguments from neorealism and neoliberalism theories. Next, the essay will look at the rationales of neorealism and neoliberalism. The essay will then offer an analysis of the 2017 trade dispute of Kazakhstan. The essay will subsequently review the reflections on the implications of the case study on Kazakhstan's foreign strategy, WTO's function in international society, and applying theories. Finally, the essay will conclude Kazakhstan's motivations for accession and compliance with WTO. Further studies may focus on the case of other post-Soviet unions and the foreign policies of Kazakhstan towards Russia during these years.

\section{LITERATURE REVIEW}

This section introduces and discusses the theoretical perspectives of neorealism and neoliberalism. The discussion of neorealism is extended by a literature review of Waltz's theories on the WTO's role. Meanwhile, the neoliberalism perspective focuses on the implications when states enter into contracts with international organizations.

\subsection{Neorealism}

Kenneth Waltz first introduced his structure-based neorealist theory of international relations in 1979. Waltz starts his work with some basic assumptions which predict certain behaviors for states. He thinks that the international system is anarchic: no higher central authority can enforce rules over individual states. Given this context, states act based on self-help. They operate with the aim of survival, and their interactions with other states reflect their desire to survive. The structure only changes if great powers take actions that will lead to a change. Most states have no power to change the structure. States will try to balance against each other because they will increase their chance of survival [3]. This paper will analyze the role of the World Trade Organization (WTO) through Waltz's definition of neorealism.

Meanwhile, the paper will also examine the growing economic interdependence between Kazakhstan and other countries. Using Waltz's theory, he found a substantial link between the number of large estates and how states act and react in the international community, such as why states create alliances, trade, and imitate each other [4]. At the same time, in Waltz's proposed theory on national security, he argues that the issue of national security is more important than rights [5]. The nature of states seeking security compels them to be wary of international cooperation and international organizations. For neo-realists, states will cooperate if their national security is not threatened. The problem is that it is difficult to ensure that national security is secure; therefore, states seeking security will be concerned about the relative gains achieved by other states through military and economic cooperation. This concern extends to one's enemies, as well as one's friends. Leaders change, and so does the nature of relations between governments. Neo-realism fails to explain much of the economic interdependence between states. If relative gains are realized, why do states trade? The answer to this question seems to go beyond Waltz's neo-realist theory, as it does not focus on power, defined as capacity. Waltz seems to suggest that states should seek to be self-sufficient and thus provide for their security and other national needs [4]. In this way, a state would not risk being cut off from food, weapons, or other resources by its enemies. Furthermore, neorealists tend to assign economic interdependence to the unitary level. Indeed, economic interdependence affects the intentions and actions of international players

\subsection{Neoliberalism}

The meaning of neoliberalism could simply be understood as a philosophical point of view towards the society highlighting aspects such as liberty, individualism, capitalism. Neoliberalist in the field of international relations tends to express and focus on aspects of beneficial to each state in events and researches, such as when one state begin a contract with one of the preexisting international organizations, there could be numerous variables at play affecting the outcomes of weather the agreements have a positive effect on either party, or whether the effects of benefits could be long term. When other ideologies examine this particular example within the realm of international 
relations, the approach could include whether joining the international organization would be safe for the state from a strategic standpoint or some ideology; joining an international organization could be a pointless and negative act. But if the said example gets examined by neoliberalists, the approach will focus more on aspects beneficial for the state joining the international organization. Neoliberalism is sometimes defined as a static set of boundaries that sets a restriction in a broad and vague point of view, but with the set of static boundaries, the ideology regulates a partial free-flowing society. This means neoliberalism basically projects in a world where the economic systems and political institutions operate in a capitalist setting and regulation but is also limited by laws and order constitutionally constructed in a democratic setting.

\section{RATIONALE}

\subsection{Rationale for Choosing neorealism}

The opposite concept to neorealism is constructivism. Constructivism holds that the behavior of people, organizations or states is socially constructed and does not follow an unchanging order or principle. Alexander Wendt introduced two central concepts of constructivism: firstly, the social structure of human beings is shaped by the dominant view of human society rather than driven by material forces; secondly, the actors that emerge on the social scene are influenced by their identity and interests rather than by their nature. However, constructivism has some weaknesses that may affect its assessment as a theoretical approach to international relations. Constructivism views issues primarily in terms of their value. Constructivists fail to explain how norms are formed, how identities are formed, and how perceived relative gains. Constructivists argue that relative gains are just another socially constructed part of international relations and that, instead, states aim to achieve only the best possible outcomes through relative or absolute gains. However, for neorealists, relative gains are an important aspect of a state's survival, which they must use to maintain their position in the international order. In summary, constructivist theory suffers from the weakness that overemphasis on conceptual structures in the international system. In order to overcome the shortcoming of constructivist theory, the essay will utilize the neorealist theory.

\subsection{Rationale for Choosing neoliberalism}

With all that being said, the reason behind deciding on adding neoliberalism approach is that, as mentioned up top, the cons of constructivism, neorealism too has a significant difference from neoliberalism, the main difference between the two parties is that neorealism is approaching the problem from a realistic point of view which tend to focus and point out the cons, although it is good always to understand the realistic approach to things, however, we could often find ourselves tunnelvisioned on the cons instead of getting the full picture. As per the reason for the introduction of neoliberalism, since neoliberalism frequently points out mostly the beneficial side of things, we could construct a full picture by understanding both approaches. When introducing terms and conditions, Kazakhstan had agreed to join the WTO since the central idea of neoliberalism is sovereignty or individualism. It was a perfect approach to explain the cooperation between Kazakhstan and the WTO, which preserves individuality but obeys rules and guidelines for the benefit of both parties. Another rationale behind the decision of neoliberalism is for the optimistic attitude towards decision making such as those involving international affairs since the decision for Kazakhstan to join the WTO essentially is for the benefit of both parties and could mostly be included as a positive decision.

\section{KAZAKHSTAN'S ACCESSION TO WTO}

\subsection{Explaining Kazakhstan's Accession to WTO from Neorealist Theory}

Neorealism tends to place greater emphasis on the state's concern with relative gains. States are seen as similar in terms of needs but differ in their capacity to realize those needs. States are seen as similar in terms of needs but differ in their capacity to realize those needs. The placement of states in terms of capabilities determines the distribution of capabilities. The structural distribution of capabilities limits cooperation between states through concerns about the relative gains achieved by other states and the possibility of dependence on other states [5]. China and most of the EU are members of the WTO, and Kazakhstan's trade with these countries confirms their recognition of Kazakhstan and provides support for Kazakhstan's accession to the WTO. Kazakhstan maintains good trade cooperation relations with many countries, such as China and the EU. China and Kazakhstan are strategic partners. Both China and Kazakhstan are important transition economies in the Asian region. Bilateral trade and investment relations and cross-border regional economic cooperation development offer good location advantages and the complementarity of resources and products. As trade and investment relations between the two countries continue to develop and cross-border regional division of labor cooperation deepens, China and Kazakhstan have become an important force in promoting regional integration in Asia.

Meanwhile, EU-Kazakhstan bilateral trade and economic relations have been developing steadily since 2002 [6]. The EU has gradually become Kazakhstan's first trading partner, accounting for nearly $40 \%$ of its total foreign trade, and Kazakhstan's exports to the EU are dominated by oil and gas, accounting for over $80 \%$ of the 
country's total exports [7]. The EU's exports are mainly machinery and transport equipment and products from the manufacturing and chemical industries. Imports from Kazakhstan greatly exceed the EU's exports to Kazakhstan. Kazakhstan's importance as a supplier of oil and gas to the EU is growing.

Nevertheless, Kazakhstan has several advantages over other Central Asian countries in terms of accession to the WTO. Kazakhstan is the largest landlocked country globally, bordering Russia, China, and most of the Middle East. In addition, the routes connecting China and Europe and the routes connecting Russia and Europe are very close to Kazakhstan, which makes it very good for foreign trade transactions compared to the other five countries. Kazakhstan has many mountains and basins, so it can attract foreign investment and therefore has the highest GDP among these countries. Secondly, the country's resources are the most important source of future economic development and the country's rich resource potential. It cannot only guarantee the current domestic supply of raw materials and energy but is also the main source of export earnings. Kazakhstan's resources are mainly derived from oil, coal, ferrous metals, and grain. At the same time, there are advantages for the Kazakh economy. These advantages will strengthen the country's economy in the short term and ensure its future economic success.

\subsection{Explaining Kazakhstan's Accession to WTO from Neoliberalist Theory}

From a Neoliberalism standpoint, the paper will mainly be observing the terms and conditions Kazakhstan has agreed to during the 20 years of negotiation. Out of all the hundreds of terms and conditions, there are three main categories that the paper will be considering, economy, trading/transport regulations, and distribution. Within the economic category, especially banking, some of the important terms from a neoliberalism standpoint include adopting measures aimed at improving risk management methods and effectiveness of banks, any private or public sectors in charge of significant amounts of funds. Simplifying requirements and procedures of foreign transactions by residents or investors. Agreeing to terms like the ones mentioned above would really improve the effectiveness and reliability of banks and companies. This could potentially create a more appealing investment environment, attract more investors, and boost the economy locally. The second major category is trading/transport regulations. Terms like granting access to government-owned/regulated pipelines to foreign investors, producing crude oil and gas on a non-discriminatory basis. Regulate customs fees of services related to the importation and exportation of goods in line with Article I of the Gatt 1994. Last but not least, replacing the import licensing requirements for encryption technology requires complicated import licensing with a one-time notification requirement. These terms mentioned about the trading/transport regulations essentially created a set of rules for Kazakhstan, which may seem like the WTO is overstepping/ controlling. However, the reason Kazakhstan agreed to those terms is that without the platform of the WTO, there really is no better way for Kazakhstan to create a fair tariff and connect with other nations without the former experience of international trade, for example, granting the access to government-owned/regulated pipelines would guarantee the profit attached with the natural resources rather than not having any route of exportation. The third major categories of terms are distribution, including implementing a transparent privatization process, as per the WTO guideline. Wholesale distribution of pharmaceutical/medical goods, to be allowed 5 years after accession. As mentioned above, the terms mentioned here would again attract more foreign investments.

\section{2017 KAZAKHSTAN'S TRADE DISPUTE WITH UKRAINE IN WTO}

In order to explain Kazakhstan's compliance and defection in WTO, the 2017 Kazakhstan trade dispute is a very good case. Why did Kazakhstan break the rules in WTO? What was the role of Kazakhstan between the Eurasian Economic Union (EEU) and WTO? What was Kazakhstan's strategic reason for joining WTO? These questions will be answered in this section.

\subsection{Specifying the Trade Dispute and Background}

"On Sept 19, 2017, Ukraine requested consultations with Kazakhstan concerning anti-dumping measures applied to certain types of steel pipes on the customs territory of Kazakhstan." [1] Specifically, the antidumping duties applied to a certain type of pipe steels on the customs territory of Kazakhstan are too high. According to WTO, these anti-dumping measures are inconsistent with several of Kazakhstan's WTO obligations.

Actually, the anti-dumping measures of Kazakhstan are in accordance with the decision of the Eurasian Economic Union (EEU). EAEU is an economic union of states located in Eastern Europe, Western and Central Asia, founded on Jan 1, 2015. It has 5 member countries currently: Belarus, Kazakhstan, Russia, Armenia and Kyrgyzstan. EEU provides common macroeconomic policies for its member countries. Greater integration can be envisioned in the future. The Union operates through supranational and intergovernmental institutions. The Supreme Eurasian Economic Council is the supreme body of the Union. And the Eurasian Economic Commission is the executive body of the Union. 
Thus, Ukraine's complaint to Kazakhstan can also be understood as its complaint to EEU. Yet, Kazakhstan does not necessarily represent EEU in this dispute since the interest of Kazakhstan may not be in accord with that of EEU.

With Ukraine's complaint initiated on Sept 19, 2017, Kazakhstan accepted the consultation organized by WTO. During this process, Russia requested to join the consultation as a third party on Oct 6 , but its request was rejected because it had already passed the 10-day deadline when Russia submitted the request. According to the WTO website, the consultation was held, but no agreement was reached, and Kazakhstan did not change its anti-dumping duty.

\subsection{Explaining the Trade Dispute from Neoliberalism}

Neoliberalism holds that countries pursue absolute advantage. Countries cooperate and form international organizations to facilitate international trade so that the absolute interest of each country will increase.

However, countries also have the incentive to defect in such cooperation. If all other countries still follow the rules, the country who defect will enjoy the benefit while not fulfilling the obligation.

In this case, Kazakhstan also has the incentive to defect the rules since higher tariffs would directly benefit Kazakhstan. There is no empirical study done in this area, so the specific extent of benefits received by Kazakhstan is unclear.

However, if we use the $3 \mathrm{R}$ theory to analyze Kazakhstan's defection, it is easy to see that there seems to be a greater potential cost on the reputation of Kazakhstan. The failure to adjust the tariff to the standard level indicates that Kazakhstan is yet unable to balance the policies in EAEU and those in WTO. Thus, it is likely for Western investors to reduce their investment in Kazakhstan since Kazakhstan's swaying between EAEU and WTO is one of their major concerns. They may worry about the obscure attitude of Kazakhstan in international trade and communication.

From this perspective, we can see that this action by Kazakhstan is exactly the opposite of what Kazakhstan has been doing these years. As we mentioned in the introduction, Kazakhstan has taken a multisectoral foreign policy and actively participated in international society during these years. It has joined in the Chinese Silk Road Economic Belt and formed EU-Kazakhstan Enhanced Partnership and Cooperation Agreement. It is unlikely for Kazakhstan to change its long hold foreign policy. So, there seem to be other reasons for Kazakhstan to defect the rules.

\subsection{Explaining the Trade Dispute from Neorealism}

Neorealism holds that countries pursue comparative advantage and safety. From the perspective of neorealism, Kazakhstan defected WTO's law due to threats from Russia and its own strategic interest.

Obviously, in this dispute, Kazakhstan was in the middle of EEU and WTO. If Kazakhstan chooses to accept the request of Ukraine, it will be viewed as a "betrayal" to EAEU since the export policies of EEU member countries will stop being the same. If Kazakhstan continues to defect the rules, it will be viewed as a "betrayal" to WTO. Either way, the interest of Kazakhstan will be harmed. The question is which side Kazakhstan would choose to follow.

To answer the question, we should first understand what it means for Kazakhstan to defect policies in each organization. On the one hand, for EEU, it is obvious that the largest and most influential country in EEU is Russia. It would create tension between Kazakhstan and Russia if Kazakhstan chose to accept the request of Ukraine. As we can see in the map provided above, Russia was located right in the north of Kazakhstan. It would be so easy for Russia to impose geopolitical and economic control over Kazakhstan. Specifically, the oil export, one of the major components of Kazakhstan's export, is largely controlled by Russia. On June 7, 2002, Kazakhstan and Russia signed an Agreement Oil Transit. "The destination and amount of Kazakhstan's oil transit will be determined by the Russian authorities and approved by the congruent decision of the Government of the Russian Federation [8].

Moreover, in recent years, Russia has been continuously increasing its military potential in Central Asia areas. Moscow is the region's largest arms supplier and has thousands of troops stationed at bases in Kazakhstan, Kyrgyzstan and Tajikistan [9]. Though the possibility of military threat is small, the pressure is large for Kazakhstan.

On the other hand, the result of defecting WTO rules is relatively small for Kazakhstan. There have been no direct economic or political sanctions on Kazakhstan up till now. Instead, according to WTO official websites, sanctions, as expected, fell upon Russia and other individual EEU countries.

From this perspective, to prevent creating tension with Russia, Kazakhstan chose to defect the WTO rules and maintain the tariff level at EEU standard.

Nevertheless, as analyzed in the last section, the longterm effect of defecting WTO rules will be much more severe for Kazakhstan. Moreover, the defection seems to be inconsistent with the long-held foreign policies of Kazakhstan. So, How will Kazakhstan act in the future? 


\section{REFLECTION AND DISCUSSION}

In this section, I will combine the analysis above with broader historical context to conclude Kazakhstan's foreign strategy and predict the future of Kazakhstan's role in WTO. Besides, the two cases analyzed here will also give implications to the WTO system.

\subsection{Kazakhstan's Foreign Strategy and Its Future Role in WTO}

Looking through Kazakhstan's interaction with foreign countries during the past 30 years, we can see that, since the 2000s, Kazakhstan has been actively participating in international cooperation and reaching out as broadly as possible, especially to large economies such as the US EU and China. In the international society, it aims to build an image of a responsible and constructive actor. According to Engvall and Cornell, "The core of that strategy has been to create several foreign policy pillars Russia, China, the US, the EU, Turkey - that are rather harmonious in size and shape. The key balancing act has been to keep the house in order by not allowing any pillar to outweigh the others totally" [10]. In this way, Kazakhstan can establish a stable international relation that promotes its economic development in the great context of globalization.

However, in recent years, It becomes much more difficult for Central Asia leaders to maintain power because the geopolitical dynamics in the region have altered. The US has drawn down forces in the region of Afghanistan, Russia has imposed greater control over the area by increasing institutionalization in EEU, and military aggression, including the annexation of Crimea, and China has proposed further economic cooperation in the region with its Silk Road Economic Belt. For Kazakhstan, the most intractable issue is with Russia. As analyzed in the last section, the geopolitical control imposed by Russia on Kazakhstan is unexceptionally large. According to Daily Nurgaliyeva, Kazakhstan has been taking soft balancing policies to Russia these years to counter Russia's control. For example, Kazakhstan looked for alternative oil export infrastructure such as the BTC pipeline that bypassed Russia to reduce its economic dependence on Russia.

From this perspective, the reason why Kazakhstan defected from WTO rules can be better illustrated. Due to Kazakhstan's overly economic dependence on Russia, it had to make concessions and defect the WTO rules temporarily. However, this does not mean Kazakhstan will continue its defection in the future.

"On June 5, 2021, Kazakhstan dismissed a senior Russian official's idea of a joint response to Western sanctions against Moscow and its allies such as Belarus by a Russia-led post-Soviet trade bloc" [11]. Russian deputy foreign minister said EEU was working on a "consolidated response" against Western Sanctions. Yet Kazakhstan's foreign minister rejected his request and said the Central Asian nation was against "politicizing" the trade bloc.

From this case, we can observe that Kazakhstan has gradually begun to reject Russia's request and counter its control. Although the Western power Kazakhstan used to rely on to maintain balance is now undermined, as the development in Kazakhstan's economy and political power, it is possible that someday Kazakhstan can gain a more independent status in foreign society and continue its policy of multisector.

\subsection{The Implication of Kazakhstan's Case for WTO}

For WTO, a large international organization, this case also exposes some internal problems in its system. Clearly, it is not the first time when WTO has conflicts with regional trade organizations. According to Dinara Nurusheva, these regional trade organizations usually complicate international trade by creating additional barriers and undermining the principles of nondiscrimination [12]. Although these organizations are usually members of WTO, it is still difficult for WTO to regulate some of their illegal actions. In the 2017 trade dispute, no agreement was reached in the WTO dispute settlement group. WTO appears to be powerless in such circumstances where the regional organization is backed up by great power. However, inside those regional organizations, the interest of each country may not be the same. Although economic sanctions toward the whole organization may not be effective, WTO may enact different policies for different individuals. In this way, some of the members in the organizations may make concessions to WTO.

In this case, if WTO initiated an economic sanction towards the whole EAEU, all the individuals would form a "consolidated resistance". Yet if it only imposes sanctions on Russia and some of its close allies, the attitude of Kazakhstan might be different.

\section{CONCLUSION}

In summary, this essay begins with a literature review of the neoliberal and neo-realist theories used in the article. Then it explains the rationale for applying neoliberalism and neorealism. After that, the essay analyses Kazakhstan's accession to the WTO and Kazakhstan's trade disputes at the WTO in 2017. The article reflects on the use of theory and presents the implications of the case study. The essay succeeds in answering the researcher's questions from a neoliberal and neorealist perspective. Furthermore, the essay deepens our understanding of Kazakhstan's accession to the WTO, Kazakhstan's diplomatic strategy, and the function of the WTO in the international community. It 
can help identify new ways to improve the WTO system and new opportunities for development in Central Asia. However, this essay has several limitations. There is insufficient evidence to support the ideas in the essay due to the lack of research on the countries mentioned above or similar countries. A single case provides limited explanations and may not fully explain other cases. Therefore, future research could focus on cases from other post-Soviet countries. Furthermore, it would be worthwhile to explore constructivist perspectives to understand the phenomenon fully.

\section{REFERENCES}

[1] WTO, Aug 2, 2021, WTO | dispute settlement - the disputes - DS517, Retrieved from https://www.wto.org/english/tratop_e/dispu_e/cases _e/ds517_e.htm

[2] Aitolkyn Kourmanova, July 2, 2015, Kazakhstan and the WTO: A New Era, Retrieved from https://www.csis.org/analysis/kazakhstan-and-wtonew-era

[3] Lundborg, T. (2019) 'The ethics of neorealism: Waltz and the time of international life', European Journal of International Relations, 25(1), pp. 229-249. doi: $10.1177 / 1354066118760990$.

[4] Waltz, K. (1988). The Origins of War in Neorealist Theory. $<\mathrm{i}>$ The Journal of Interdisciplinary History, $</ \mathrm{i}\rangle\langle\mathrm{i}>18</ \mathrm{i}\rangle$ (4), 615-628. doi:10.2307/204817

[5] Bordner, B. (1997). Rethinking Neorealist Theory: Order Within Anarchy. [online] Brucebordner.com. Available <http://brucebordner.com/Neorealism.html> [Accessed 19 August 2021].

[6] Carman, J. M. (2004). Thinking Strategically: The Major Powers, Kazakhstan, and the Central Asian Nexus. Journal of Macromarketing, 24(1), 66-68. https://doi.org/10.1177/0276146704264010

[7] Satpaev, D., 2015. Kazakhstan and the Eurasian Economic Union: The view from Astana. [online] ECFR.

Available at: $<$ https://ecfr.eu/article/commentary_kazakhstan_ and_the_eurasian_economic_union_view_from_ast ana395/> [Accessed 26 August 2021].

[8] Lyailya Nurgaliyeva, 2014 October, Kazakhstan's economic soft balancing policy vis-à-vis Russia: From the Eurasian Union to the economic cooperation with Turkey Retrived from https://www.sciencedirect.com/science/article/pii/S 1879366515000317

[9] Dimitri Simes JR. , May 27 2021, Russia fortifies Central Asia military clout before US Afghan exit, Retrieved

from
https://asia.nikkei.com/Politics/Internationalrelations/Russia-fortifies-Central-Asia-militaryclout-before-US-Afghan-exit

[10] Johan Engvall and Svante E. Cornell, December 2015, Asserting Statehood: Kazakhstan's Role in International Organizations, Retrieved from https://www.silkroadstudies.org/publications/silkro ad-papers-and-monographs/item/13178-assertingstatehood-kazakhstans-role-in-internationalorganizations.html

[11] Reuters, June 5 2021, Kazakhstan rebuffs talk of joint sanctions response with Russia, Retrieved from https://www.reuters.com/world/asiapacific/kazakhstan-rebuffs-talk-joint-sanctionsresponse-with-russia-2021-06-05/

[12] Dinara Nurusheva, July 22 2016, Kazakhstan in the "Spaghetti Bowl": Cooperation between the EAEU and the WTO, Retrieved from https://www.silkroadstudies.org/publications/silkro ad-papers-and-monographs/item/13178-assertingstatehood-kazakhstans-role-in-internationalorganizations.html 